\title{
Interkonnektivitás, új média és digitális identitás a regionális kutatásban. Koncepcionális megközelítés ajánlásokkal
}

\author{
Interconnectivity, new media and digital identity \\ in regional science
}

\author{
FEHÉR KATALIN
}

FEHÉR Katalin: tudományos főmunkatárs, Budapesti Gazdasági Főiskola Kutatóközpont; feher.katalin@kkk.bgf.hu

KULCSSZAVAK: interkonnektivitás, új média, régió - digitális identitás, regionális identitás

ABSZTRAKT: A tanulmány átfogó javaslatokat fogalmaz meg a regionális kutatások számára az interkonnektivitás, az új média és a digitális identitás témakörében - társadalomtudományi megközelítéssel. Célom bemutatni azokat a trendeket és forrásokat, melyek együttesen szoros átfedést mutatnak a megjelölt témakörökben és kijelölni a vizsgálatokhoz szükséges alapfogalmakat, jelenségeket. A munka először az interkonnektivitás és a digitális ökoszisztéma alappilléreit vizsgálja, alkalmazva az információs és hálózati társadalom kapcsolódó forrásainak kiemelt következtetéseit, majd az új média vonatkozó, aktuális trendjeiről adok rövid betekintést, megemlítve az augmentálódó és virtualizálódó környezetek egyes feltörekvő innovációit térbeli kontextusban. A regionális és lokális digitális identitás kutatási lehetőségeit ez alapján definiálom, kiemelve a földrajzi-társadalmi (geo-social) média és az online kontextuális beágyazottság szempontjait. A kulcskérdések, a legfontosabb fogalmak és trendek összefoglalása mellett a tanulmány végül ajánlásokat fogalmaz meg a jövőbeni regionális kutatásokhoz: mely vizsgálati területek, eszközök és módszertani megfontolások váltak megkerülhetetlenné.

Katalin FEHÉR: senior research fellow, Budapest Business School Research Centre; feher.katalin@kkk.bgf.hu

KEYWORDS: interconnectivity, new media, identity of regions, regional identities

ABSTRACT: This paper proposes a comprehensive conceptual approach to interconnectivity, new media and digital identity in order to research locality of interest within the framework of social science. The goal is to present the trends and sources of overlapping subjects, to enhance basic research concepts and to investigate core phenomena.

In our conclusion we provide an overview of the major constituents of interconnectivity and those of digital ecosystems relating to key concepts of a networking society. The trends of current new media resources, including augmented and virtualised environments with trending formats of development in a geospatial context from augmentation to remote-controlled services are briefly discussed. The regional and local choices for research concerning digital identity are

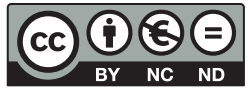


defined according to those subjects, with special foci on geo-social media and on contextual online embeddedness.

In addition to the discussion of basic research concepts and an overview of what has been trending, the study makes topical and methodological recommendations for future empirical research.

We generally recommend a hybrid research design for regional science when dealing with new technologies, especially the digital revolution. Mapping physical networks and penetration rates are the first steps to understanding online competitiveness. We propose that management or administrative inquiry into economic and social interconnectivity is to be measured (a) via the selection of nodes in online networks focusing on digital identities and (b) via big-data analytics based on online databases with automated or partly manual analytics. Online topology and content analysis are also essential as they focus rather on volume, relations and flows than on strict sampling and data sets. The schematic or modelling illustrations with topologies, static or dynamic visual tools from infographics to real time migration maps can generate the data-driven support of decision making in marketing.

The phenomenon of new media suggests further analysis using digital tool and content systems as engines in interconnectivity. Top-down communication via conservative and internet-based regional mass media and institutions, and bottom-up communication by collective or individual users via social/forum/blog media platforms provide clues to research on hidden trends. Measuring and monitoring political, economic, cultural, religious and opinion leader activities as well as educational, traditional, historic and natural values are preserved in different types of online representations. Digital identities are embedded in representation structures and also in interconnectivity. Their roles, identification and impacts provide an explanation of workflow in regional and local contexts. On the other hand, inactivity, hidden contents or anonymity are most probably relevant characteristics from a different perspective.

Finally, we may need to set up "a map of digital trends" consisting of test units for the superimposition of real (time) results. With this test method, multi-dimensional research with marketing-decision enhancement becomes available in a socio-economic context for regional science.

\section{Bevezetés}

A tanulmány a Budapesti Gazdasági Főiskola Kutatóközpontban zajló Regionális hálózatkutatás - a Zselic példája címü projekt részeként jött létre. Célja egyfelől támogatni egy előkészítés alatt álló empirikus kutatást a Zselic térségében, valamint egy rokon szakmából megfogalmazni releváns és aktuális szempontokat, jelenségeket a digitalizáció és mediatizáció társadalomtudományi kontextusáról, s ezen keresztül ajánlásokat adni a regionális kutatások számára.

Az online hálózatok koncepcionális megközelítése abból indul ki, hogy az internetes és közösségi hálózatoknak vannak aktorai vagy felhasználói, azonosítható csomópontjai, intézményesített vagy személyes szándékokhoz kötött megjelenési formái, melyek a szakirodalmi háttérrel és az aktuálisan kapcsolódó trendek kiemelésével vizsgálhatók. A témakör igen szerteágazó, hiszen az online hálózatoknak, az online trendeknek, a reprezentatív szerepü digitális identitásnak, valamint a regionális kutatásoknak egyaránt széles körü irodalma érhető el. Ahhoz, hogy egy jól fókuszált keret jöjjön létre, a szakirodalmi hátteret alaposan meg kellett szürni. Erre nemcsak a rendelkezésre álló szakirodalom volumene és különböző megközelítései miatt volt szükség. Fontos volt 
lehatárolni azokat a témákat, melyek az elemzéshez szorosan tartozhatnak és le kellett választani azokat, melyek a felsorolt témaköröket együttesen nem érintik. $\mathrm{Az}$ itt bemutatott kutatás éppen ezért négy, szorosan összekapcsolódó területre koncentrált, melyek a következők: 1. Interkonnektivitás és digitális ökoszisztéma, 2. Új média és a valóságérzékelés digitális kiterjesztése, 3. A digitális identitás: adatkészletek, azonosíthatóság és anonimitás, 4. Regionális/lokális identitás a digitális mediatizációban.

Azokat a forrásokat kezeltük bejövőként, melyek a négy terület metszetében, vagy ezek közül legalább kettő szoros összefüggésében és kontextushelyesen kapcsolódnak. Ezután tovább szürtük a forrásokat, evidenciaként kezelve, hogy minél frissebb szakirodalmakra van szükség a folyamatosan változó digitális és „okos” (smart) környezetben, a legújabb tudományos eredmények megismerésére. Már klasszikusnak nevezett, sokoldalúan hivatkozott források is fent maradtak a szűrőn: elsősorban ezek biztosítják a közvetlen kapcsolatot a kutatás központi célkitűzéseihez és terminológiájához. Célunk az volt, hogy az itt összefoglalt források közös metszete támogassa a módszertani és mintavételi eljárásokat egy későbbi primer kutatási szakaszban vagy bármely vonatkozó empirikus megközelítésben.

\section{Interkonnektivitás és digitális ökoszisztéma}

Az internetes hálózatkutatás egyik kiemelt, leginkább mérnöki és informatikai területe a fizikai hálózatok létrehozásához kapcsolódik. A digitális és okos technológia elérhetővé tétele újraírja a korábbi helyi és állami gyakorlatokat (Sylvain 2013). A technológia és a hozzá fejlesztett online szolgáltatások (Komninos, Tsarchopoulos 2012), illetve a kapcsolódó platformok és az információs iparágak újratermelik a hálózati logikát. Mind a szolgáltatások, mind a tartalmak újra és újra hálózatba rendeződnek azokkal az egyéni vagy kollektív aktorokkal és felhasználókkal, akik transzparens vagy kevésbé transzparens funkcióik szerint müködtetik a humán vagy automatizált rendszereket.

A fizikai hálózatokra, az azokból építkező platformokra, szolgáltatásokra és tartalmakra, az állandó interaktivitásra is igaz, ami az offline összekapcsoltságra: ezek valóságkonstrukciók, illetve társadalmi konstrukciók, melyek újra- és újratermelődnek (Faragó 2007; Gáspár 2005). A digitális hálózatokban létrehozott adatok, információk és üzenetrendszerek bináris kódok komplex kapcsolataivá alakítják át az offline valóságot és újmédia-tartalmak linkelt összehuzalozásává fordítják le azt. Így jön létre egyrészről az ún. big data vagy adatrobbanás, másrészről a hipermédia.

A big data hatalmasra duzzadt, digitálisan létrehozott vagy továbbított adattömeg, mely a hagyományos adatelemzés megoldásaihoz képest túl nagy és komplex adathalmazokat képez. A big data felhasználása új elemzési megköze- 
lítést hív elő az elfogadható pontosságú eredmények és az optimális adatfeldolgozási idő érdekében (Snijders, Matzat, Reips 2012). Az előremutató megoldások a digitális hálózatokat és az azokhoz kapcsolódó eszközöket, szenzorokat, közösségimédia-aktivitásokat, elemzéstámogató szoftvereket, a navigációt és a logisztikát, a természeti és társadalmi környezetben kiszámítható elmozdulásokat tekinti alapnak. Kulcsszavai a big datán belül a smart data és a mintázat (Cavallaro et al. 2014). A smart data kiemeli a használható vagy cél szerint alkalmazható adatkészleteket, attribútumokat a teljes adathalmazból, különböző szűrési és elemzési feltételekkel. A jellemző mintázatok keresése az együttállásokra és korrelációkra fókuszál, például a gyakran és az ugyanazokon a hálózati pontokon előforduló aktivitásokra, visszatérő netes keresztlinkelésekre - ezzel támogatva különböző társadalmi vagy üzleti döntéseket. Mind a big data, mind a mintázatkövetés esetében vizuális eszközök segítik az elemzést. Jellemző példák a statikus illusztrációkra az infografikák, a szófelhők vagy metrótérképekhez hasonló topológiák. Dinamikus, akár azonos idejű mintázatokat rajzolhatnak ki azok a szoftverek, melyek például migrációs térképeken mutatják meg az aktuális áramlásokat vagy a közösségi médiában való tevékenységeket vetítik rá a digitalizálódó városok elektronikus szolgáltatásaira. Az adatvezérelt döntések egyre gyakrabban hagyatkoznak ezekre az általában leegyszerüsíto", integráló, összegző vizuális megoldásokra.

A hipermédia (Nelson 1965) szerkesztetté, láthatóvá, hallhatóvá, olvashatóvá, illetve tartalmivá teszi az egyes adatkészleteket és nemlineáris médiumként hiperlinkeken keresztül kapcsolja össze ezeket. Ma mindez különböző platformokon és okos eszközök alkalmazásain keresztül érhető el, jelentős része interaktív és biztosítja az azonos idejű elérést.

Kiindulópontként létezik tehát egy fizikai hálózat, melyhez egyre több nem mobil és mobil eszköz kapcsolódik, ezek biztosítják a bejövő, elemezhető és archivált, egyre növekvő adatkészletek mozgását és elérését, a hipermédiára vetítve pedig a platform és tartalmi hálózatok létrejöttét és percepcióját. A fizikai hálózatok rendszeres elérésén múlik egy-egy régió vagy ország internetpenetrációja is, mely alapvető gazdasági és társadalmi mutató: a teljes népesség körében határozza meg, hogy hányan férnek hozzá az internethez. Első körben tehát a fizikai hálózat, az ahhoz különböző szolgáltatásokon keresztül kapcsolódó eszközök és a (mobil- vagy internet)penetráció mutatói írják le egy adott régió beágyazottságát a digitális környezetekbe, illetve mutatnak rá a potenciális versenyképességre.

Manuel Castells $(2005,2006,2007)$ klasszikus trilógiájában az „információ koráról", a hálózati társadalom felemelkedéséről ír, ahol az internet története, gazdasági és társadalmi szerepe, az identitás új nézőpontja jelenti az alapvető fogalmi hálót. Castells a nyitottságot tekinti a digitális hálózatok alaptermészetének, mely a jelenlegi gazdasági és társadalmi változások kiindulópontjává vált, létrehozva egy új paradigmát. Szoros összefüggésbe hozható ez a megközelítés az üzleti és menedzsmenttanulmányokban elterjedt holisztikus nézőponttal Håkan Håkanssonnak köszönhetően (2010, 37.), csak a logika fordított 
Castells elméletéhez képest. Nemcsak az offline hálózatokra vált érvényessé a kutatók és elemzők szemében, hanem az internetet vizsgálva lett igazán magától értetődo”: „Nem létezik egyetlen objektív hálózat. Nincs »helyes« vagy teljes leírása a hálózatoknak. A hálózatok nem egy adott vállalat hálózatai. Egyetlen vállalat sem birtokolja. Egyetlen vállalat sem irányítja, bár mindegyik azt szeretné. Egyetlen vállalat sem áll a hálózat középpontjában. Nincs »központja«, bár sok vállalat azt gondolhatja, hogy ők állnak a középpontban."

Ugyanígy egy társadalomnak vagy egy közösségnek sincs egyetlen központja. Vannak létrejövő és eltűnő központjai, ezek arányai, méretei, szerepei azonban folyamatosan változnak. A Google keresőmotor sokak számára például megkerülhetetlen, így bizonyos értelemben központtá vált, de ezeknek a központoknak előbb-utóbb kialakulnak elágazásai vagy alprojektjei, ahogyan a Google cég ma már az Alphabet Inc. része, jövője pedig a keresőmotoros fejlesztések helyett inkább az „okos” (smart) megoldásokról szól. Konkurenciája például a Baidu, mellyel Kínában nem tudott versenyre kelni: az adott régió kontextusa és nyelve nem támogatta a globális trendet. Sőt, ha az idődimenziót vizsgáljuk, a sűrűsödések, csomópontok, központok elmozdulása viszonylag rövid időn belül bekövetkezhet: az Altavista mint korábbi online kereső eltűnt a mezőnyből, az Internet Live Stats Real Time Statistics Project jövőbemutató megoldása pedig kiszolgál olyan funkciót is azonos időben, amelyet a klasszikus keresőmotorok már nem tudnak. És mindössze húszéves távlatról beszélünk.

A hálózatban léteznek nézőpontok, csomópontok vagy hubok, ezek azonban csak adott időintervallumban érhetők el, és sosem egy központhoz viszonyítva. Az internetes hálózatok rámutatnak arra, hogy valójában mindig csak egy-egy metszetet látunk. Az interkonnektivitás a meghatározó, ahol a felhasználók a számítógépek által mediatizált kommunikációban keresik a helyüket (Burnett, Kazmer, Dickey, Chudoba 2003; Rheingold 2002), s a végül az ezen keresztül behálózottak egyszerre léteznek a valós életben és a digitális interakciókban (Wellman 2001), ahol a közös célok felülírhatják a fizikai közelség szükségességét (Baym 1997; Haythornthwaite, Kazmer, Robins, Shoemaker 2000).

Ma már klasszikussá vált egy természettudományos kutatásokon nyugvó fogalom is, a skálafüggetlen hálózat (Barabási 2003), mely a fokszámeloszlás aszimmetriáját vizsgálja. A skálafüggetlen hálózatban kevés pontnak van sok kapcsolata, s egy-egy átmenet végén a többség már csak néhány kapcsolattal rendelkezik. Az internet tipikusan ebbe a körbe tartozik mind fizikai, mind platform- és tartalmi hálózatként, sőt, identitáshálózatként is. A mai tudományos és piaci környezetben kiemelt figyelmet kapnak a sok kapcsolattal rendelkező pontok, melyekből egy-egy hálózatban kevés van, de az információelosztás ezeken keresztül zajlik, illetve azok a pontok is, melyeken „kifut” az információ. Mindeközben érdemes visszaidézni az előző bekezdésből: ezekből a központokból mindig több van, s a központok időben megszünnek, létrejönnek, cserélődnek, szerepük a hálózaton belül változik és mindössze aktuális állapot szerint elemezhetők vagy értékelhetők. Nincs tehát egyetlen központ vagy egyetlen hálózat. Az internet a hálózatok hálózata. 
Szükség van tehát olyan hálózati kompetenciákra, döntési vagy sűrűsödési pontok felismerésére, illetve a folyamatok lekövetésére, melyek az összekapcsoltságban segítik a releváns információk elérését, előmozdítják a versenyképességet vagy a kooperációt (Keiner, Kim 2007; Veres, Feher, Balogh 2014). Kompetenciaportfóliók (Vlasyuk 2010) épülnek mind az egyedi, mind az intézményesített felhasználóknál, melyek együttmüködéseket és további célokat határoznak meg.

$\mathrm{Az}$ internetes hálózatok koncentráltabb és periferikusabb pontjain információ és tőke mozog, melyek feltérképezése erőforrássá vált. A heterogénebb hálózatokban kiemelten használható a skálafüggetlenség: egyes csomópontok önkéntesen válhatnak központivá egy-egy célkitüzés mentén. Projektek, vállalkozások, start-upok és küldetések kérhetik fel a hálózat tagjait együttműködésre (Jardim-Goncalves et al. 2013; Kim 2013). A kollaboratív hálózatok összekötőként működnek egy adott cél eléréséhez adott időszakban, és keretet biztosítanak az innovációra törekvő együttműködéseknek. A kollaboráció így lett alapvető működési elv az online innovációkban.

Az online hálózatot tehát nyitottság, interkonnektivitás és kollaboráció jellemzi, ahol a csomópontok és a kapcsolódások helye változó, a célok és lehetőségek határozzák meg - az interaktivitáson alapuló digitális hálózatok így lettek a társadalmi, gazdasági és kulturális változások eredői. A heterogén hálózatok kiaknázhatók, a digitális adatkészletek aranybányának tekinthetők, a gyorsan változó platform- és tartalomkínálat további innovációra ad lehetőséget. Összefoglalva a digitális hálózati megközelítés elsősorban egy fizikai alapokra épülő, de a fizikai beágyazottságot egyre inkább láthatatlanná tevő, virtualizáló szemléletet javasol a regionális hálózatkutatásban. Elsősorban adathalászó és -elemző, tartalmi és kollaborációs hálózatokra koncentráló, big data és hipermediális megközelítéssel vizsgálható egy régió vagy hely digitális megjelenése, mely az offline hálózatok valóságával vethető össze.

\section{Új média és a valóságérzékelés digitális kiterjesztése}

A média valóságformáló, illetve társadalmi konstrukciós szerepe meghatározó. Napirendeket ad, kiemeli egy-egy hálózatból a csomópontokat, információkat, tartalmakat, közvetítőket, az ezekhez tartozó helyeket és tereket. Online agendáról (Havlik et al. 2011) beszélünk, amikor a tömegmédia műsorrendje találkozik az intézményi és közigazgatási kommunikáció napirendjével, valamint a felhasználói tartalommal. Üzeneteik sokoldalú érintettséget és szempontokat hordoznak a lokálistól a globális beágyazottságig.

A média tömegkommunikációs és digitális hálózati szerepei szimbolikus közvetítőként is értelmezhetők: pszichológiai megalapozást adnak az entitásnak, hogy elhelyezze magát (Schudson 1995, 15.) a földrajzi és társadalmi térben. Különösen fontos ez a mai globális médiakontextusban (Appadurai 1996; 
Chung 2010), ahol online jelentéssel is fel kell tölteni a térbeliséget, ahol le kell horgonyozni mindazt, ami lokálisan érvényes, ahol megmutathatók a társadalmi és kulturális azonosítók, s ahol a digitális platformokat ismerőssé, illetve könnyen azonosíthatóvá kell tenni vagy globális-univerzális vizualizációval és szolgáltatásokkal, vagy lokális-anyanyelvűvé tett megoldásokkal.

A média kulturálisan ki tudja termelni a befogadható jelentést és nézőpontokat ad a globalizált világhoz (Howley 2011, 129.). A formális alapokon nyugvó, regionálisan elérhető médiát (Bowd 2007; Buchanan 2009; Franklin 2006; Hutchins 2004), illetve a közösségi újságírást is (Lauterer 2006; Lowrey, Brozana, Mackay 2008; McManamey 2004; Reader, Hatcher 2012) folyamatosan formálja az ,alulról jövő" kommunikáció. A civil, az állampolgári, a lakossági online aktivitás (részben) publikus sokszínűsége az interaktív hipermédia következménye (pl. kommentszekció a híroldalakon, fórum és véleményfolyam a közösségi médiában, kevésbé ellenőrzött tartalmak szórása a különböző hálózatokban vagy épp a közvetlenebb információkat biztosító blogforrások, szemben a hírmédia szolgáltatásaival). A felhasználói tartalom termelésének, illetve az ezeket megosztó és szétosztó online hálózatoknak köszönhetően multipoláris médiakörnyezet jött létre és formálódik jelenleg is. Az okos és mobil eszközök azonnali hozzáférést és közvetítést, állandó információfogyasztást és -szűrést tesznek lehetővé, ami folyamatosan termeli az erre vonatkozó keresletet. A térbeliséggel értelmezett változatban ez „geo-social” (Buchanan 2009), azaz földrajzi jelenség - az ezzel szorosan összefüggő társas vagy társadalmi hírvilággal. A szimbólumok és a rítusok lehorgonyozzák mindezt, a regionálisan jelentős marketingkommunikáció pedig ebből építkezik (Lukasik 2011).

A mediatizált felületek közül kiemelendők a feltörekvő mobil platformok és szolgáltatások, melyek hibrid megközelítést adnak a már meglévő gyökerekhez és elvárási struktúrákhoz (Paasi 1986, 2002). A helyhez kötött bejelentkezéseket, a navigációt, az események egyidejü értékelését teszik lehetővé, s önmagában ezzel online közvetítés jön létre. Ilyenek például az okos eszközökre telepíthető mikroprogramok vagy alkalmazások, melyek bekapcsolásával látható, kik vagy mik esnek egy földrajzi ponthoz a legközelebb. Innentől egy-egy hely az ott jelenlévőkkel és az ott a zajló eseményekkel együtt címkézhető, az így keletkező információk helyhez kötötten termelődnek tovább, big data elemzéssel pedig visszacsatolhatók például egy szolgáltatás frissítéséhez. Minden lehetőséges előny mellett ezek a szolgáltatások komoly adatbiztonsági kérdéseket is felvetnek az interaktív kommunikációban (Jabeur, Zeadally, Saye 2013). Az e-részvételtől a mobil részvétel felé mozdul el az online jelenlét (de Reuver, Stein, Hampe 2013), ami számos jogi és morális kérdést vet fel.

A helyszínekkel, a határvonalakkal és a fizikai mozgás terével kapcsolatban kiemelt, feltörekvő jelenségként említhetők az augmentált valóság alkalmazásai és a távirányítható mobil eszközök. Az előbbi már létező, offline valóságot terjeszt ki virtualizált rétegekre helyezett információkkal, az utóbbi pedig korábban részben vagy nem elérhető helyszíneket, egyedileg szerkesztett né- 
zőpontokat és látványokat mutat meg. Mindkét esetben valóságérzékelés-kiterjesztésről beszélünk.

Az augmentált valóság esetén a helymeghatározás támogatja a vetített képre helyezhető új információkat és kiemeléseket (Azuma 1997; Metz 2012). Az érdeklődés pontjai (POI, points of interest) határozzák meg, végül mi lesz a vetített képen a többletinformációs réteg. Először az aktuális, jelen lévő fizikai környezet látható a képernyőn. A helyalapú, virtuális elemek automatizáltan vetülnek rá erre, vagy egy másik megoldással a fizikai környezet kiemelt elemei hoznak létre virtuális elemeket. Közérdekű, eseményekhez kapcsolódó, szolgáltatás-központú információkat lehet így belevetíteni a helyhez kötött, valós idejü vizuális megjelenésbe. A geomediatizált megoldások a mindennapi gyakorlattól (pl. gyalogos navigációhoz kapcsolódó, a láthatóságot kiemelő alkalmazásoktól) egészen a szimulációs játékokig vezetnek (pl. augmentált fiktív játék, mely újraírja a globális és regionális narratívákat - Chess 2014).

A távirányítható kamerák és mediatizált szolgáltatások közül a drónok ma a legfelkapottabb eszközök, melyek a nehezen megközelíthető, illetve a költségesen elérhető helyekre jutnak el távirányítással vagy automatizált (ön)szabályozással, pilóta nélkül. A katonai célú megoldásoktól ma már eljutottunk a postai kézbesítéshez, az emberi élet kockázatát kímélő szempontoktól az idő- és költségkíméléshez. A megfigyelés, felderítés, célmegjelölés mellett megjelentek a civil szolgáltatások és médiakísérletek (pl. természeti katasztrófa esetén dokumentumfilm forgatása pilóta nélkül). A drónkamera feltörekvő médiaforma (Stahl 2013), számos, még feltáratlan kérdéskörrel - az adatvédelemtől és sebezhetőségtől a morális problémákig. Előnyei azonban jól láthatók szélsőséges helyzetekben és különleges helyszíneken. Magyarországi példája a Narmageddon néven helyi kezdeményezéssel forgatott drónfilm, amely a Normafa 2014. decemberi természeti katasztrófájáról ad közeli és felülnézeti képeket szerkesztett formában. Nemzetközi példája lehet a CNN professzionális szemléltető videósorozata a nepáli földrengésről a városkép különböző metszeteitől az emeletenként szétvált épületek megközelítéséig.

A média és az új média együtt létező paradigmájában tehát számos lehetőség van a térbeliség megmutatására, a helyszíni beágyazottság felcímkézésre és értelmezésére, szimbolikus keretbe helyezésére, aktualizálására - a tömegmédia műsorrendjétől a közösségi média véleményfolyamáig, valamint a valóságérzékelés digitális kiterjesztésétől a felderítő médiumig. A kérdés az, hogy a mediatizált hálózatok egyes pontjai, illetve entitásai hogyan válnak azonosíthatóvá.

\section{A digitális identitás: adatkészletek, azonosíthatóság és anonimitás}

Az identitás olyan valami, amellyel egy entitás egyedülállóan rendelkezik, azaz az identitás megkülönböztet másoktól (Buckingham 2008). Identitása lehet egy 
személynek, de az identifikáció aktusának értelmében intézmény, vállalat vagy más entitás is rendelkezhet identitással. Határvonal a társas és társadalmi kontextusban, ami tulajdonságokkal ruház fel (Wenger 1998). A digitális identitás ennek online elérhető adatkészlete, ami jelöli, hogy az adott digitális lábnyomok mely entitásokkal konzisztensek, és azt is, hogy melyekkel nem konzisztensek. A big data kontextusában a felhalmozódó adatkészletekből egyes adatkészletek (vagy metaforikusan digitális lábnyomok) azonosítanak entitásokat hálózataik dinamikájában (Fehér 2013, 2014).

A közösségi és professzionális hálózatok, valamint a keresési, adat- és tartalmi hálózatok határozzák meg az online beágyazottságot és a visszacsatolásokat az offline világra. Gyakorlatilag a kevert offline-online identitások válnak természetessé (Baker 2009; Walther, Parks 2002): az identitás összetett jelenség, $\mathrm{s}$ ahogy adatkészlete növekszik, egyre inkább a lét digitális aspektusai kerülnek előtérbe (Foresight Future Identities 2013). Gyakran felkészülten ér minket egy első valós találkozás egy személlyel, üzleti partnerrel, termékkel vagy szolgáltatással: a profilok, a digitális lábnyomok és hálózataik, a fogyasztói tesztek elöre vizsgálhatók, a térbeli mozgások és az időben jellemző előfordulások egyes elemei nyilvános rendszerekben követhetők, s így egyes aktivitások megjósolhatók pusztán előzetes online információkból. A mobilhasználók városi előfordulási mintázatait feltérképező kutatás (González, Hidalgo, Barabási 2008) például aggregált adatokkal dolgozva a viselkedés előrejelzési lehetőségeit mutatta be - még a big data jelenség nevesítésének hajnalán.

A közösségimédia-analízis felől közelítve a kontextuális és reprezentációs elemzés (Edwards et al. 2013; Housley, Fitzgerald, 2002, 2009) vált meghatározóvá. Ezek a kutatások épp a digitális lábnyomok témakörében kapnak kiemelt figyelmet, többek között a piaci előrejelzésekben (pl. IBM 2012). A digitális történetmesélés elemzései a bonyolultabb narratívákat is feldolgozzák, s ennek komoly szerep jut az online közösségépítésben (Bromley 2010), több társadalmi és üzleti funkcióban is. A többségi társadalom ez alapján válhat el-/befogadóvá (Kapitzke 2000) egy-egy témakörben, egy-egy helyen vagy régióban.

A mobil eszközök megjelenésével, a globális-lokális összekapcsoltság szorosabbra füzésével folyamatosan újraíródik az identitás, amelyet ebben a formában nehezebb meghatározni; a társas, társadalmi vagy kollektív kontextusban nem rögzíthetők egyszerüen (Olwig, Hastrup 1997). Tovább nehezíti az identifikációt a globális és technológiai hatás a térbeliségre és a helyre. A helyi homogenitás csökken (Massey 1995), az időbeliség kumulálja az amúgy is összetett jelenségeket (Palfrey, Gasser 2008), a világ más részei beszüremlenek és virtuálisan vannak jelen. Többszörös identitások jönnek létre különböző adatkészletek mentén. Mindeközben az online színterek szabályait tanulják a résztvevők, online identitásunk pedig folyamatosan formálódik (Blanchard, Markus 2007).

Végül egyes identitások az anonimitás, rejtőzködés vagy inaktivitás mellett döntenek: a turizmusszektorban például a szolgáltatásokat a többség csak megfigyelésre használja (Scott, Orlikowski 2014), vagy hozzászólások esetén 
felhasználói becenevet adnak meg, melyekkel névtelenül értékelhetnek (lásd pl. Tripadvisor vagy booking.com), avagy inaktívak maradnak különböző okok miatt. A felhasználói tartalom mennyisége és minősége az anonimitás, a rejtőzködés vagy az inaktivitás ellenére is meghatározó azok számára, akik az adott helyre vagy régióba szeretnének látogatni vagy szakmai-üzleti kapcsolatok építéséhez keresnek optimális telephelyet. Egyes funkciókban vagy helyszíneken pedig egyáltalán nem célszerủ az online láthatóság, például kormányzati székből vagy hadműveleti területen. Másik oldalról ezek a funkciók még inkább keresettek az online hálózatokban. A nyomkeresés virtualizálódott.

\section{Regionális és lokális identitás a digitális mediatizációban}

A regionális identitás hívószóvá vált a politikai, a város- és a kulturális földrajzban, illetve a regionális fejlesztési gyakorlatban (Vainikka 2013, 35.). A regionális versenyképesség vizsgálatához megfelelo" fogalom (Paasi 2013), térbeli identitást és léptéket tesz elérhetővé (Paasi 2012), a régiók vagy a régiót képviselők azonosításához szükséges, illetve a szolidaritáson és bizalmon alapuló intézményi sűrűséget rajzolja ki (Keating 2001; MacLeod 1998). A régiók Európája kontextusban kiemelt szerepet kap mint történelmileg függő struktúra - intézményes és szimbolikus határokkal (Paasi 2002), melyeket többek között a digitalizált média vetít ki.

A régiók identitása mindeközben fetisizálódik: aktoraik és azok hálózatai offline, illetve online reprezentálódnak és együttesen társadalmi és gazdasági célokhoz rendelődnek. A régióba identitások linkelődnek és az identitás a régióba linkelődik - a térszervezés gyakorlatán, a jelentésteli téren, a szimbolikus formákon, a társas és társadalmi gyakorlaton, az intézményrendszeren keresztül (Paasi 2002).

Regionális kontextusban két megközelítést kell elválasztani egymástól (Abello, Bosch, Sanz 2013; Boman, Berg 2007; Govers 2014; Herb, Kaplan 1999; Komninos, Tsarchopoulos 2012; Paasi 1986; Tiru, Saluveer, Ahas, Aasa 2010; Tuan, 1974; Zimmerbauer 2011 alapján):

1. A régiók identitása: a régió azonosíthatósága, megkülönböztetés más régióktól - elsősorban természeti, kulturális jellemzők alapján, illetve politikai, gazdasági, turisztikai és más diskurzusok szerint olyan keretfogalmakkal, mint a hely szelleme vagy márkaértéke, a humanista földrajz vagy a térbeliséghez tartozó kreativitás. Valamennyi diskurzus online elérhető és folyamatosan visszacsatol offline eredőjére.

2. A régióhoz kapcsolódó intézményesített vagy személyes identitás, regionális öntudat: ott élö vagy aktív, ott még vagy már nem aktív személyek azonosulása a régióval, a kultúrával és a természeti környezettel, kapcsolódás a meglévő struktúrákhoz. Az aktorok felől nézve ez érzelmi 
vagy pszichológiai koncepció, intézményesített formában a történelmi és kulturális identitásra épül - az intézményesített forma pedig kutatásés promócióigényes. Online intimitását, az egy kattintással való hozzáférést a közösségi média, illetve a vallási és morális meggyőződés online reprezentációja rajzolja ki.

A régió identitása és a regionális identitás két különböző vizsgálati mezőt jelent ugyanabban a metszetben, részben fogalmi átfedésekkel. Online vizsgálatukhoz keresztlinkeléseiket kell figyelembe venni, illetve a nagyobb csomópontokat és a kifutási pontokat együtt szükséges vizsgálni a skálafüggetlen beágyazottság miatt. A földrajzi kontextusból linkelt adatok (Goodwin, Dolbear, Hart 2008) támogatják az azonosíthatóságot a fenti két kategóriához, a megkülönböztetést a globális és más régiókhoz kapcsolódó adatokhoz képest. Van den Bos és Nell (2006) megközelítésében a mobilitás, a transznacionális migráció és az online kommunikáció deterritorializációt eredményeznek. A deterritorializált hálózatok ideális típusa a véletlenszerü csomópontok és kapcsolatok struktúrái és az azokra épülő elosztás, ahol a megfigyelések mindössze néhány társadalmi ténnyel leírhatók. A valódi típus esetén azonban a territoriális határok elmosódottak, a mobilitás és az offline-online kevert interkonnektivitás hatására változó képet kapunk, az új média vegyíti a lokálpatrióta mechanizmusokat a migrációval és más dinamikákkal, ezért csak többféle adatfelvétel és társadalmi elemzési módszer együttesével írhatók le a vizsgált hálózatok. A linkelt helyek, a fókuszált weboldalak, alkalmazások, tartalmak referenciális értéke, a big data alapján szürt és elemzett adatok, a különböző augmentált és virtualizált médiajelenségek, valamint a „geo-social” vagy geomediatizált digitális lábnyomokon alapuló azonosítás és megkülönböztetés válik meghatározóvá a regionális kutatás online dimenziójában.

\section{Ajánlások}

Egy régió digitális hálózatának és penetrációjának feltérképezéséhez először a fizikai hálózatok és elérési pontok arányait és az internetes, online, mobil felhasználói szokásokat szükséges mérni, összehasonlítani és elemezni.

Közgazdasági, gazdálkodási vagy közigazgatási vizsgálat esetén a régió gazdasági és társadalmi interkonnektivitását és versenyképességét javasolt feltérképezni, 1. a kijelölt vagy azonosított (személyes vagy intézményesített) csomópontok gyakorlatának és tapasztalatainak megkérdezésével, illetve 2. statisztikai és tartalomelemzéssel az interneten, online adatbázisokban, automatizált analitikákban, platformokon elérhető információk alapján.

Ajánlott külön vizsgálni a regionális tömegmédia, a régió identitásához kapcsolódó, felülről jövő, valamint a regionális identitáson alapuló, alulról jövő kommunikációs hálózatokat - felkutatva a kevés, de nagy számú kapcsolattal 
rendelkező csomópontokat, valamint a kifutó vagy feltörekvő perifériákat. Érdemes folyamatosan frissíteni információinkat az elterjedőben levő augmentációs és virtuális trendekről, melyek egyes csatornák és platformok szerepét rövid idő alatt módosíthatják.

Az eredmények digitálisidentitás-elemzéséhez és a fentiek szerint kapott eredmények finomhangolásához szükség van a politikai, gazdasági, kulturális, vallási, illetve a véleményformáló, ismeretterjesztő, hagyományőrző, történelmi és természeti értékeket őrző, közösségi, innovatív, újmédiaeszközök és a közösségimédia-reprezentáció vizsgálatára.

Javasolt továbbá ellenőrizni és integrálni az eredményeket a régió társadalmi-földrajzi digitális identitása, reputációja, deterritorializációs hatása, illetve interkonnektivitása alapján. Ezen belül a jól azonosítható hálózati csomópontok mellett érdemes becsléssel meghatározni az online kevésbé látható elemeket és azok funkcióinak arányát, ezzel csökkentve az anonimitásból, rejtőzködésből vagy inaktivitásból eredő torzítást.

Az ajánlások célhoz rendelt módszertannal valósíthatók meg. Kiemelten javasolt a statisztikai adatok komparatív elemzése a big data lehetőségeinek alkalmazásával, ahol a kinyerhető adatok volumene és hasznosíthatósága, a nagyságrendek és az összefüggések előnyt élveznek a korábbi statisztikai módszerek pontosságigényével szemben. Az online elérhető szoftveres analitikák beépítése, akár azonos idejű méréssel és megfigyeléssel további dimenziót biztosítanak az elemzéshez. A tartalomelemzés kiaknázása alapvetővé vált, elsősorban a feltáró kutatási lépésekhez és az eredmények pontosabb megértéshez. A hálózati topológia és más, a tanulmányban említett adatvizualizációs eszközök használata mindezek alapján szemlélteti az eredményeket, támogatva a részletekben el nem vesző döntéshozást. A további finomhangoláshoz online fókuszcsoportok is felépithetők, melyek aktuális csomópontok és események elemzésére szolgálhatnak vagy panellé építve longitudinális monitoringot biztosíthatnak.

Végül, de nem utolsó sorban az adott vizsgálati időszak „digitális trendtérképét” érdemes rávetíteni a vizsgálati egységekre a valós (idejü) eredmények érdekében. Mindez együtt támogatja a többdimenziós kutatásokat, illetve a döntések előkészítését a társadalmi és gazdasági mikro- és makrofolyamatokban.

\section{Köszönetnyilvánítás}

Ezúton szeretnék köszönetet mondani a Budapesti Gazdasági Főiskola Kutatóközpontjának az EMMI-26130-2/2013/TUDPOL számon biztosított kutatási feltételekért. Külön köszönettel tartozom a projekt integrációjáért a nagy léptékű Zselic-kutatáshoz Solt Katalin kutatóközpont-vezetőnek és Gáspár Tamásnak, a kutatóközpont szakmai koordinátorának. 


\section{Irodalom}

Abello, J. M. C., Bosh, M. D., Sanz, J. L. M. (2013): Technology versus religion. In: Proceedings of 2013 International Conference on the Modern Development of Humanities and Social Science. Atlantis Press, 257-260. http://doi.org/8wj

Appadurai, A. (1996): Modernity at large: Cultural dimensions of globalisation. University of Minnesota Press, Minneapolis

Azuma, R. (1997): A survey of augmented reality. Teleoperators and Virtual Environments, 4., 355-385.

Baker, A. J. (2009): Mick or Keith: blended identity of online rock fans. Identity in the Information Society, 2. 7-21. http://doi.org/ft223m

Barabási A.-L. (2003): Behálózva. Magyar Könyvklub, Budapest

Baym, N. (1997) Interpreting soap operas and creating community: Inside an electronic fan culture. In: Keisler, S. (ed.), Culture of the internet. Lawrence Erlbaum Associates, Mahwah, 103-120.

Blanchard, A. L., Markus, L. M. (2007): Technology and community behavior in online environments. 3rd International Conference on Communities and Technologies, Michigan State University, Lansing, június 28-30. http://doi.org/bp2sd9

Boman, J., Berg, E. (2007): Identity and institutions shaping cross-border co-operation at the margins of the European Union. Regional and Federal Studies, 2., 195-215. http://doi.org/dxmzqz

Bowd, K. (2007): A voice for the community: Local newspaper as local campaigner. Australian Journalism Review, 2., 77-89.

Bromley, R. (2010): Storying community: Re-imagining regional identities through public cultural activity. European Journal of Cultural Studies, 1., 9-25. http://doi.org/cdr9m7

Buchanan, C. (2009): Sense of place in the daily newspaper. The Journal of Media Geography, 4., 62-84.

Buckingham, D. (ed.) (2008): Youth, identity, and digital media. The MIT Press: Cambridge

Burnett, G., Kazmer, M., Dickey, M., Chudoba, K. (2003): Inscription and interpretation of text: A cultural hermeneutic examination of virtual community. Information Research, 1., 162-174.

Castells, M. (2005, 2006, 2007): Az információ kora I-III. A hálózati társadalom kialakulása; Az identitás hatalma; Az évezred vége. Gondolat, Infónia, Budapest

Cavallaro, G., Riedel, M., Benediktsson, J. A., Goetz, M., Runarsson, T., Jonasson, K., Lippert, T. (2014): Smart data analytics methods for remote sensing applications. Geoscience and Remote Sensing Symposium (IGARSS), IEEE International, 1405-1408. http://doi.org/8wk

Chess, S. (2014): Augmented regionalism: Ingress as geomediated gaming narrative. Information, Communication \& Society, 9., 1105-1117. http://doi.org/8wm

Chung, P. (2010): The emerging media exchange in the cultural regionalization of Asia. In: Jin, D. Y. (ed.) Global media convergence and cultural transformation. IGI Global, Hershey, 80-93. http://doi.org/cj9k2f

Edwards, A., Housley, W., Williams, M., Sloan, L., Williams, M. (2013): Digital social research, social media and the sociological imagination: surrogacy, augmentation and re-orientation. International Journal of Social Research Methodology, 3., 245-260. http://doi.org/8wn

Faragó L. (2007): Térstruktúra: térideák és megvalósításuk a településhálózat-fejlesztésben. Tér és Társadalom, 4., 21-38.

Fehér K. (2013): Vállalati digitális identitás. In: Horváth D., Bauer A. (szerk.): Marketingkommunikáció. Stratégia, új média, fogyasztói részvétel. Akadémiai Kiadó, Budapest, 124-134.

Fehér K. (2014): Milyen stratégiák mentén épül fel a digitális identitás? Feltáró kutatási szakasz: a munkavállalás előtt álló egyetemisták. Médiakutató, 2., 139-154.

Foresight Future Identities 2013. https://www.gov.uk (Letöltés: 2015. november 1.)

Franklin, B. (2008): The future of newspapers. Journalism Studies, 5., 630-641. http://doi.org/fbmqxk

Gáspár T. (2005): Idő-tér-korszakváltás. In: Hideg É. (szerk.): Társadalmi tér, idő, téridő a jövőkutatásban. Budapesti Corvinus Egyetem Jövőkutatás Tanszék, Budapest, 82-107.

Gonzále,z M. C., Hidalgo, C. A., Barabási, A.-L. (2008): Understanding individual human mobility patterns. Nature, 453., 779-782. http://doi.org/cwtw4h

Goodwin, J., Dolbear, C., Hart, G. (2008): Geographical linked data: The administrative geography of Great Britain on the semantic web. Transactions in GIS, 1., 19-30. http://doi.org/frt3gz 
Govers, R. (2014): Rethinking virtual and online place branding. In. Kavaratzis, M., Warnaby, G., Asgworth, G. J. (eds): Rethinking place branding. Springer, 73-83.

Håkansson, H. (2010): Határtalan hálózatok - Az üzleti kapcsolatok menedzsmentjének új szemlélete. Alinea Kiadó, Rajk László Szakkollégium, Budapest

Havlik, D., Schade, S., Sabeur, Z. A., Mazzetti, P., Watson, K., Berre, A. J., Mon, J. L. (2011): From sensor to observation web with environmental enablers in the future internet. Sensors, 4., 3874-3907. http://doi.org/b5dxzt

Haythornthwaite, C., Kazmer, M., Robins, J., Shoemaker, S. (2000): Community development among distance learners: Temporal and technological dimensions. Journal of Computer Mediated Communication, 1. http://doi.org/fh7qsc

Herb, G., Kaplan, D. (eds.) (1999): Nested identities. Rowman \& Littlefield, New York

Housley, W., Fitzgerald, R. (2002): The reconsidered model of membership categorization analysis. Qualitative Research, 1., 59-83. http://doi.org/fbzj4b

Housley, W., Fitzgerald, R. (2009): Membership categorization, culture and norms in action. Discourse \& Society, 3., 345-362. http://doi.org/bxg8pb

Howley, K. (2011): Understanding community media. Sage, Thousand Oaks

Hutchins, B. (2004): Castells, regional news media and the information age. Continuum: Journal of Media and Cultural Studies, 4., 577-590. http://doi.org/b84fcj

IBM (2012): Fast track to the future. The 2012 IBM tech trends Report. http://www-03.ibm.com/ systems/hu/resources/fast_track_to_the_future_the_2012_ibm_tech_trends_report.pdf (Letöltés: 2015. november 1.)

Jardim-Goncalves, R., Agostinho, C., Sarraipa, J., Grilo, A., Mendonça, J. P. (2013): Reference framework for enhanced interoperable collaborative networks in industrial organisations. International Journal of Computer Integrated Manufacturing, 1-2., 166-182. http://doi.org/8wp

Jabeur, N., Zeadally, S., Saye, B. (2013): Mobile social networking applications. Communications of the ACM, 3., 71-79. http://doi.org/8wq

Kapitzke, C. (2000): Information technology as cultural capital: Shifting the boundaries of power. Education and Information Technologies, 1., 49-62. http://doi.org/ft7scq

Keating, M. (2001): Rethinking the region. Culture, institutions and economic development in Catalonia and Galicia. European Urban and Regional Studies, 3., 217-234. http://doi.org/fvtnfj

Keiner, M., Kim, A. (2007): Transnational city networks for sustainability. European Planning Studies, 10., 1369-1395. http://doi.org/bxhptp

Kim, S.-T. (2013): Next generation e-government strategies and asks for the smart society - based on Korea's case. Journal of E-Governance, 1., 12-24.

Komninos, N., Tsarchopoulos, P. (2012): Toward intelligent Thessaloniki: from an agglomeration of apps to smart districts. Journal of Knowledge Economy, 2., 149-168.

Lauterer, J. (2006): Community journalism: Relentlessly local. University of North Carolina Press, Chapel Hill

Lowrey, W., Brozana, A., Mackay, J. B. (2008): Toward a measure of community journalism. Mass Communication and Society, 3., 277-299. http://doi.org/fpvjwv

Lukasik, S. J. (2011): Protecting users of the cyber commons. CommUniCations of the ACM, 9., 54-61. http://doi.org/cmf3px

MacLeod, G. (1998): In what sense a region? Place hybridity, symbolic shape, and institutional formation in (post-),odern Scotland. Political Geography, 7., 833-863. http://doi.org/fcmh5q

Massey, D. (1995): The conceptualization of place. In: Massey, D., Jess, P. (eds.): A place in the world, The Open University Press, Oxford, 45-85.

McManamey, R. (2004): The relationship between community newspapers and social capital: The power to empower. PhD thesis, University of Tasmania. http://eprints.utas.edu.au/283 (Letöltés: 2015. november 1.)

Metz, R. (2012): Augmented reality is finally getting real. Technology Review, 2. http://www.technology review.com/news/428654/augmented-reality-is-finally-getting-real/ (Letöltés: 2015. november 1.)

Nelson, T. (1965): Complex information processing: a file structure for the complex, the changing and the indeterminate. Proceedings of the 20th ACM National Conference. ACM, Cleveland, 84-100. http://doi.org/b7vfmk 
Olwig, K. F., Hastrup K. (eds. 1997): Sitting culture. Routledge, London

Paasi, A. (1986): The institutionalization of regions: A theoretical framework for understanding the emergence of regions and the constitutions of regional identity. Fennia, 1., 105-146.

Paasi, A. (2002): Bounded spaces in the mobile world: deconstructing 'regional identity'. Tijdschrift voor Economische en Sociale Geografie, 2., 137-148. http://doi.org/b9ccwx

Paasi, A. (2012): Regional identities. In: Anheier, H., Juergensmeyer, M. (eds.): Encyclopedia of global studies. SAGE, Thousand Oaks, 1454-1457. http://doi.org/8wr

Paasi, A. (2013): Regional planning and the mobilization of 'regional identity': from bounded spaces to relational complexity. Regional Studies, 8., 1206-1219. http://doi.org/8ws

Palfrey, J., Gasser, U. (2008): Born digital. Basic Books, New York

Reader, B., Hatcher, J. (2012): Foundations of community journalism. Sage, Thousand Oaks http://doi.org/8wt

Reuver, M. de, Stein, S., Hampe, J. F. (2013) From eParticipation to mobile participation: Designing a service platform and business model for mobile participation, Information Polity, 1., 57-73.

Rheingold, H. (2002): Smart mobs: The next social revolution. Perseus, Cambridge

Schudson, M. (1995): The power of news. Harvard University Press, Cambridge

Scott, S. V., Orlikowski, W. J. (2014): Entanglements in practice: Performing anonymity through social media. MIS Quarterly, 3., 873-893.

Snijders, C., Matzat, U., Reips, U. D. (2012): “Big data”: Big gaps of knowledge in the field of internet. International Journal of Internet Science, 1., 1-5.

Stahl, R. (2013): What the drone saw: the cultural optics of the unmanned war. Australian Journal of International Affairs, 5., 659-674. http://doi.org/8wv

Sylvain, O. (2013): Wireless localism: Beyond the shroud of objectivity in federal spectrum administration. Michigan Telecommunications and Technology Law Review, 1., 121-170. http://doi.org/8ww

Tiru, M., Saluveer E., Ahas, R., Aasa, A. (2010): Web-based monitoring tool for assessing space-time mobility of tourists using mobile positioning data: Positium barometer. Journal of Urban Technology, 1., 71-89. http://doi.org/br45qh

Tuan, Y. (1974): Topophilia. A study of environmental perception, attitudes and values. Prentice-Hall, Englewood Cliffs

Vainikka, J. (2013): The role of identity for regional actors and citizens in a splintered region: The case of Päijät-Häme, Finland. Fennia, 1., 25-39.

Van den Bos, M., Nell, L. (2006): Territorial bounds to virtual space: transnational online and offline networks of Iranian and Turkish-Kurdish immigrants in the Netherlands. Global Networks, 2. 201-220. http://doi.org/fh5bkz

Veres, Z., Feher, K., Balogh, A. (2014): Impact of corporate network competences on the competitiveness of companies. European Scientific Journal, 10., 259-269.

Vlasyuk, G. V. (2010): Resources of social enterprise. Sage, ACB, Moscow

Walther, J. B., Parks, M. R. (2002): Cues filtered out, cues filtered in. Computer-mediated communication and relationships. In: Knapp, M. L., Daly, J. A. (eds.): Handbook of interpersonal communication. 3rd edition. Sage, Thousand Oaks, 529-563.

Wellman, B. (2001): Physical place and cyber place: The rise of networked individualism. International Journal of Urban and Regional Research, 2., 227-252. http://doi.org/br8hxf

Wenger, E. (1998): Communities of practice learning, meaning, and identity. Cambridge University Press, London http://doi.org/8wx

Zimmerbauer, K. (2011): From image to identity: Building regions by place promotion. European Planning Studies, 2., 243-260. http://doi.org/bctjd8 